\title{
The dynamic mechanism of post-rift accelerated subsidence in Qiongdongnan Basin, northern South China Sea
}

\author{
Zhongxian Zhao $\cdot$ Zhen Sun $\cdot$ Zhenfeng Wang $\cdot$ \\ Zhipeng Sun · Jianbao Liu • Zhangwen Wang • \\ Longtao Sun
}

Received: 10 April 2013/ Accepted: 9 August 2013/Published online: 22 August 2013

(C) The Author(s) 2013. This article is published with open access at Springerlink.com

\begin{abstract}
A 1-D unloaded tectonic subsidence (air-loaded tectonic subsidence) model is proposed and applied to the Qiongdongnan Basin. Results show that three episodes of subsidence exist in Cenozoic, that is, syn-rift rapid subsidence (Eocene-Oligocene) with subsidence rate at 20-100 $\mathrm{m} / \mathrm{m} . \mathrm{y}$, post-rift slow thermal subsidence (early-middle Miocene) around $40 \mathrm{~m} / \mathrm{m} . \mathrm{y}$., and post-rift accelerated subsidence (since late Miocene) $40-140 \mathrm{~m} / \mathrm{m} . \mathrm{y}$., which is substantially deviated from the exponentially decayed thermal subsidence model. For exploring the mechanism of post-rift accelerated subsidence, the faulting analyses are conducted and results show that there is a dramatically decrease in the numbers of active faults and fault growth rate since $21 \mathrm{Ma}$, which indicates that no active brittle crust extension occurred during post-rift period. Furthermore, previous studies have demonstrated that the stretching of the upper crust is far less than that affecting the whole crust. Therefore, we infer that the lower crust thinned during the post-rift period and a new model of basin development and evolution is put forward to explain the post-rift accelerated subsidence and depth-dependent crust thinning in the Qiongdongnan Basin, which is supported by gravity data.
\end{abstract}

Keywords Accelerated subsidence - Unloaded tectonic subsidence $\cdot$ Lower crust thinning - Depthdependent crust thinning · Qiongdongnan Basin

Z. Zhao $(\bowtie) \cdot$ Z. Sun $\cdot$ J. Liu $\cdot$ Z. Wang $\cdot$ L. Sun CAS Key Lab of Marginal Sea Geology, South China Sea Institute of Oceanology, Chinese Academy of Sciences, Guangzhou 510301, China

e-mail: zxzhao@scsio.ac.cn

Z. Wang $\cdot$ Z. Sun

Zhanjiang Branch of CNOOC Limited, Zhanjiang 524057, China

\section{Introduction}

Qiongdongnan Basin, located at the western end of the northern continental margin of South China Sea, is mainly composed of a shelf and adjacent deepwater depressions, rich in oil and gas resources (Zhu et al. 2012; Zhang 2010).

The Cenozoic tectonic setting of the Qiongdongnan Basin is complicated, and is impacted by the mutli-episodic, multi-directional stretching of South China Block (Ru and Pigott 1986; Zhou et al. 1995), as well as the sinistral and dextral strike-slip of the Red River Fault (Harrison et al. 1992; Sun et al. 2003; Xiang et al. 2004), and multi-phase spreading of the South China Sea (Briais et al. 1993; Li et al. 2011). In Qiongdongnan Basin, an episode of accelerated subsidence exists during the post-rift (Li et al. 1998), which is dramatically deviated from the exponential decayed thermal subsidence in the typical Atlantic continental margin (Steckler and Watts 1978). However, the specific time and location of the accelerated subsidence are still in debate. Lei et al. (2011) and Song et al. (2011) argued that the accelerated subsidence occurred since Pliocene (5.3 Ma); In contrast, Li et al. (1998), Xie et al. (2006), Tian (2010), Li et al. (2012) proposed that it happened during and after the late Miocene (10.5 Ma); Yuan et al. (2008) believed that it took place since late Miocene $(10.5 \mathrm{Ma})$ in the west but since the Pliocene (5.3 Ma) in the east. New data and methods are employed to explore when, where and how the accelerated subsidence happened.

\section{Geologic setting}

Qiongdongnan Baisn, trending NE, experiences EoceneOligocene extension and a Neogene-Quaternary post-rift 


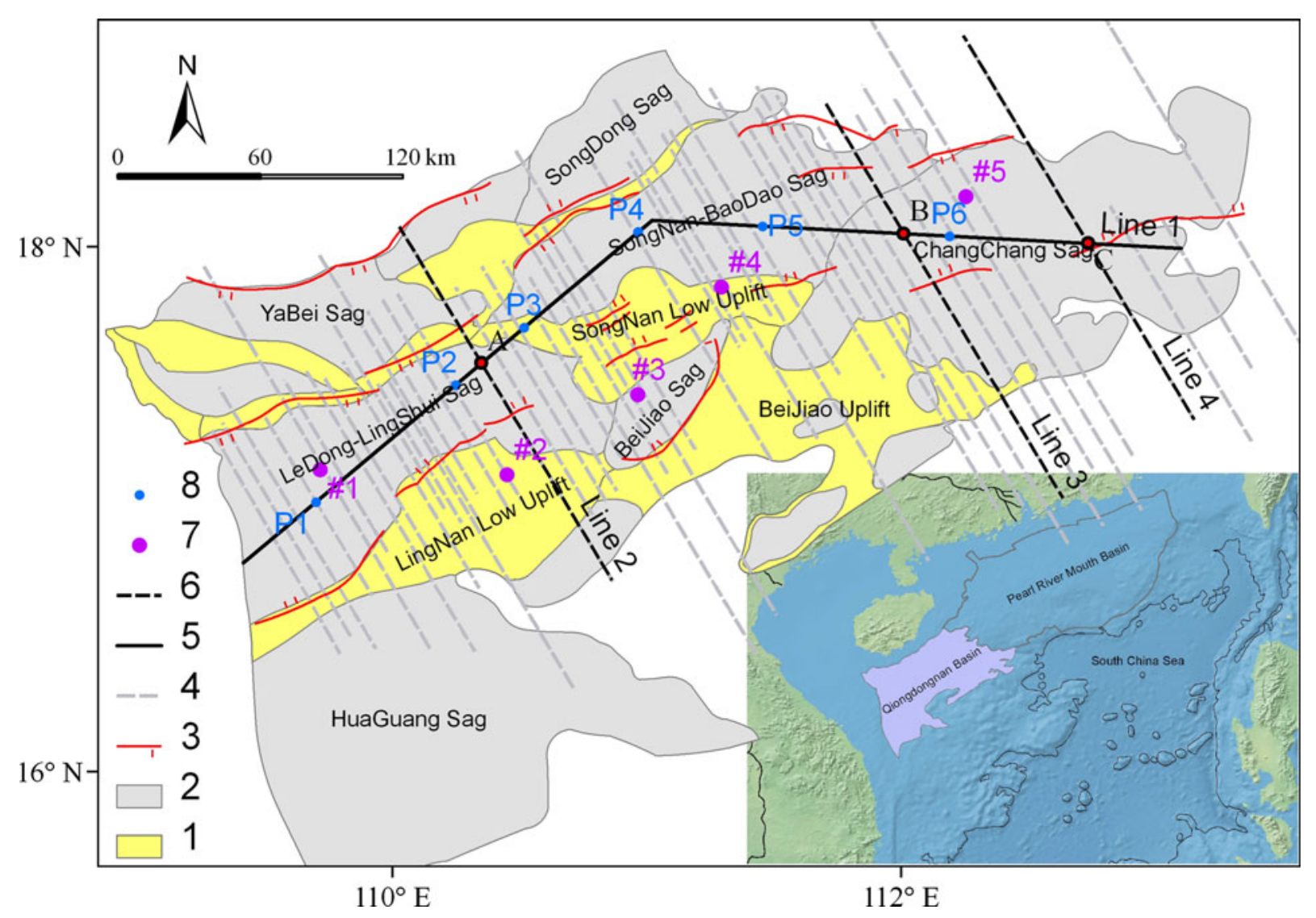

Fig. 1 Simplified structures and distribution of data source in Qiongdongnan Basin (1-uplift, 2-sag, 3-faults, 4-seismics lines used for faulting analysis, 5-seismic section named line 1 for backstripping, 6-line 2, 3 and 4 for gravity inversion (A, B, C are the intersection points of line 2 , line 3 , line 4 with line 1 , respectively), 7-lithological wells, 8-bacstripped points selected from line 1.), the inset map showing the northern continental margin of South China Sea with pink area denoting Qiongdongnan Basin

\section{Characteristics of unloaded tectonic subsidence in Qiongdongnan Basin}

One-dimensional unloaded tectonic subsidence (airloaded tectonic subsidence) reconstructions

Tectonic subsidence is the amount of subsidence that would have been experienced by the basement if it had only been airloaded and is generally considered to have been caused by the inner tectonic force of the earth, that is the unloaded tectonic subsidence or air-loaded tectonic subsidence (Wu et al. 2003). This unloaded tectonic subsidence is calculated after adjusting for the loading effects of water and sediment. Much research has utilized the water-loaded basin subsidence as the tectonic subsidence (Watts and Ryan 1976; Steckler and Watts 1978; Sclater and Christie 1980). Technically the water-loaded basin subsidence is not the true tectonic subsidence, because it contains the water induced isostatic subsidence. Understanding the uplift or subsidence of basement in the absence of a water-load correction makes quantifying basin subsidence 
Fig. 2 One-dimensional unloaded tectonic subsidence model

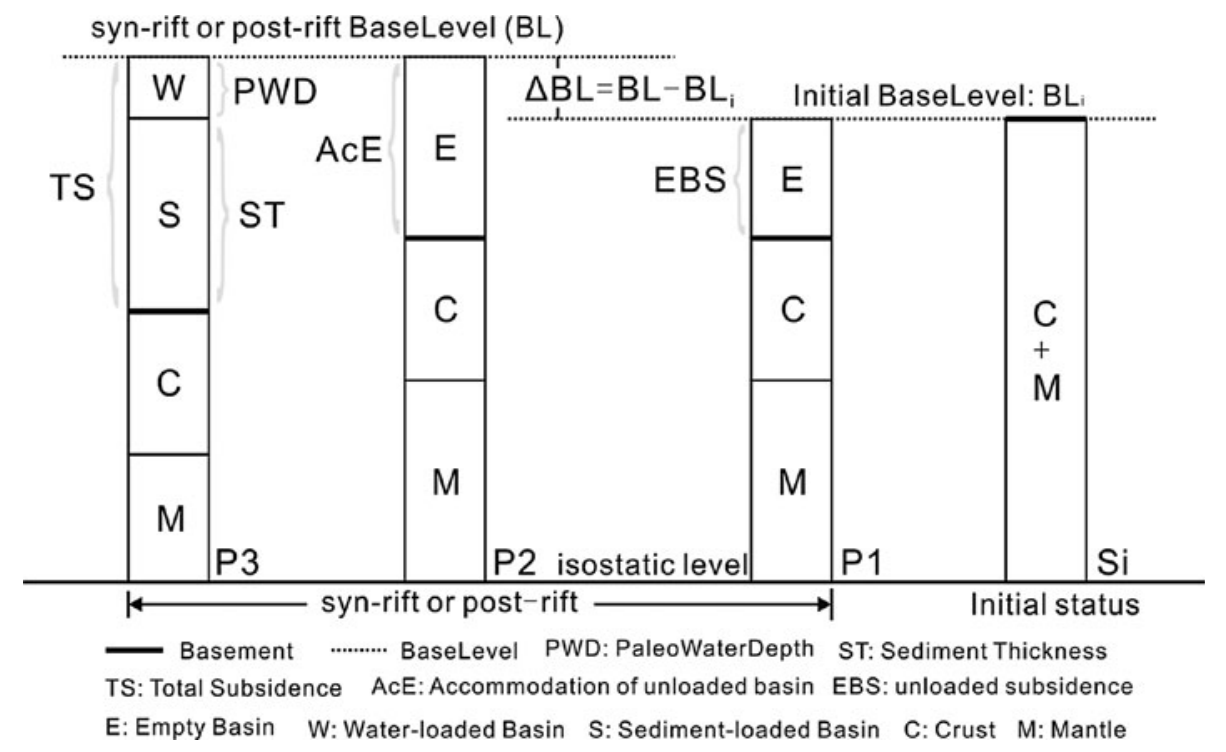

more difficult. As a result, A 1-D unloaded (i.e., water and sediment unloaded) tectonic subsidence model (Fig. 2) is developed and the formula of unloaded tectonic subsidence is established under the assumption of Airy isostasy. Unloaded tectonic subsidence is the true tectonic subsidence without any load induced isostatic subsidence, which makes the concept of tectonic subsidence clear and the analysis of dynamic mechanism easier.

The above model (Fig. 2) assumes Airy isostasy, without considering the effect of lithospheric effective elastic thickness. $S i$ in Fig. 2 indicates the initial state and $P 1, P 2, P 3$ correspond to three different processes at a given time after $S i$. $B L_{i}$ is the initial baselevel, $B L$ is the baselevel at a given time after $S i$ and $\triangle B L=B L-B L_{i}$ is the change of baselevel. The total subsidence $(T S)$ is the sum of the paleowaterdepth $(P W D)$ and the decompacted sediment thickness (ST) (Formula 1). The unloaded accommodation (AcE) is obtained by removing the water and sediment-induced isostatic subsidence from the total subsidence, as shown in Formula 2. By subtracting the baselevel change $(\triangle B L)$ from the $A c E$, the empty basin or unloaded tectonic subsidence $(E B S)$ is calculated (Formula 3). Therefore, the unloaded tectonic subsidence $(E B S)=$ total subsidence $(T S)$ - water and sediment induced isostatic subsidence- baselevel change $(\triangle B L)$.

$T S=S T+P W D$

$A c E=S T \times \frac{\rho_{m}-\rho_{s}}{\rho_{m}}+P W D \times \frac{\rho_{m}-\rho_{w}}{\rho_{m}}$

$E B S=S T \times \frac{\rho_{m}-\rho_{s}}{\rho_{m}}+P W D \times \frac{\rho_{m}-\rho_{w}}{\rho_{m}}-\Delta B L$

where $\rho_{w}, \rho_{s}, \rho_{m}$ is the average density of water, sediment and mantle.

The formula of total subsidence rate (TSR), unloaded accommodation rate (AcER) and unloaded tectonic subsidence rate (EBSR) between any two time $(\mathrm{k} \rightarrow \mathrm{n}, \mathrm{k}>\mathrm{n})$ are given as follows (Formulas 4-6).

$$
\begin{aligned}
T S R_{k-n}= & \left(T S_{n}-T S_{k}\right) /(k-n) \\
= & {\left[S T_{n}+P W D_{n}-\left(S T_{k}+P W D_{k}\right)\right] /(k-n) } \\
A c E R_{k-n}= & \left(A c E_{n}-A c E_{k}\right) /(k-n) \\
= & {\left[\left(S T_{n}-S T_{k}\right) \times \frac{\rho_{m}-\rho_{s}}{\rho_{m}}\right.} \\
& \left.+\left(P W D_{n}-P W D_{k}\right) \times \frac{\rho_{m}-\rho_{w}}{\rho_{m}}\right] /(k-n) \\
E B S R_{k-n}= & \left(E B S_{n}-E B S_{k}\right) /(k-n) \\
= & {\left[\left(S T_{n}-S T_{k}\right) \times \frac{\rho_{m}-\rho_{s}}{\rho_{m}}\right.} \\
& +\left(P W D_{n}-P W D_{k}\right) \times \frac{\rho_{m}-\rho_{w}}{\rho_{m}} \\
& \left.-\left(B L_{n}-B L_{k}\right)\right] /(k-n)
\end{aligned}
$$

As the water-loaded basin subsidence is extensively used in the current and previous literatures (Watts and Ryan 1976; Steckler and Watts 1978; Sclater and Christie 1980), the relationship between unloaded tectonic subsidence (EBS), water-loaded basin subsidence (WBS) and sediment-loaded basin subsidence (SBS) are illustrated in Fig. 3 and are also expressed in Formulas 7 and 8.

$$
\begin{aligned}
W B S & =E B S \times \frac{\rho_{m}}{\rho_{m}-\rho_{w}} \\
& =S T \times \frac{\rho_{m}-\rho_{s}}{\rho_{m}-\rho_{w}}+P W D-\Delta B L \times \frac{\rho_{m}}{\rho_{m}-\rho_{w}} \\
S B S & =E B S \times \frac{\rho_{m}}{\rho_{m}-\rho_{s}}-\rho_{w} \\
& =S T+P W D \times \frac{\rho_{m}}{\rho_{m}-\rho_{s}}-\Delta B L \times \frac{\rho_{m}}{\rho_{m}-\rho_{s}}
\end{aligned}
$$




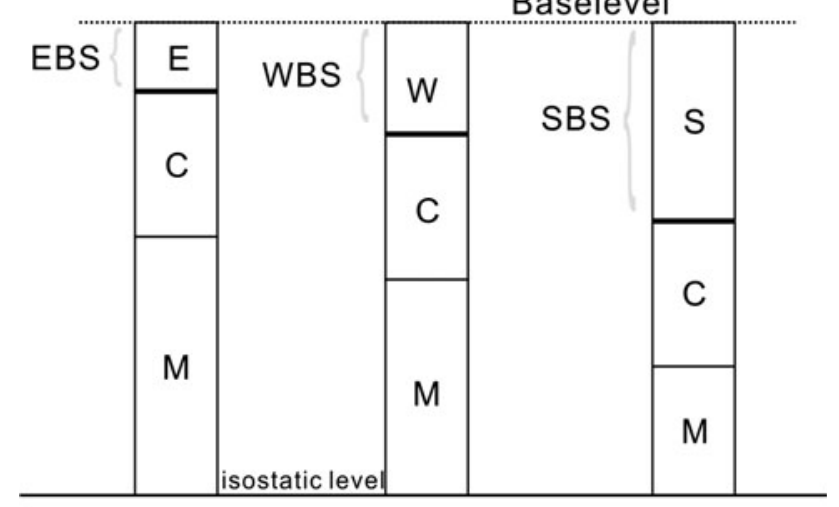

EBS: Unloaded Subsidence WBS: Water-loaded Basin Subsidence SBS: Sediment-loaded Basin Subsidence

Fig. 3 The relationship between unloaded tectonic subsidence (EBS), water-loaded basin subsidence (WBS) and sediment-loaded basin subsidence

In Formulas 7 and 8, we use a mantle density of $3,184 \mathrm{~kg} / \mathrm{m}^{3}$, a water density of $1,030 \mathrm{~kg} / \mathrm{m}^{3}$, and an average sediment density of $2,400 \mathrm{~kg} / \mathrm{m}^{3}$. The water-loaded basin subsidence (WBS) is approximately 1.5 times the unloaded tectonic subsidence (EBS) and the sediment-loaded basin subsidence (SBS) is about four times the unloaded tectonic subsidence (EBS).

Characteristics of unloaded tectonic subsidence in Qiongdongnan Basin

The 1-D unloaded tectonic subsidence technique is applied to Line 1 with nine sequence boundaries dated at $45,36,30$, 23, 21, 15.5, 10.5, 5.5 and $0 \mathrm{Ma}$ (Fig. 4) from CNOOC. The section cuts through the central depression and is time-depth converted, decompacted and backstripped under the constraint of the time-depth relationship, lithology and paleowaterdepth of five wells from CNOOC (\#1, \#2, \#3, \#4, \#5) in the deepwater area (Fig. 1). The lithologic parameters are derived from the Baiyun Sag deepwater in the Pearl River Mouth Basin (Zhao et al. 2011) and the sea level reconstruction of Haq et al. (1987) is applied. The unloaded tectonic subsidence rate of Line 1 (Fig. 5) is calculated and six points along the line are selected to be analyzed in detail (Fig. 6). Point 1 lies in the LeDong Sag, Point 2 locates in the LingShui Sag, Point 3 sits on the SongNan Low Uplift, and Points 4, 5 and 6 are in the SongNan, BaoDao and ChangChang Sags respectively (locations see Figs. 1, 4).

According to Figs. 5 and 6, the evolution of unloaded tectonic subsidence in Qiongdongnan Basin can be classified into three stages: syn-rift subsidence, post-rift slow subsidence, and post-rift accelerated subsidence.

1. Syn-rift tectonic subsidence during Eocene-Oligocene (45-21 Ma). Subsidence rate varies from 20 to $100 \mathrm{~m} /$ m.y. with the smallest value beneath the SongNan Low uplift (See P3 in Figs. 5, 6). The amplitude of the subsidence rate curve (Fig. 5a) oscillates largely laterally showing the features of syn-rift tectonic subsidence. However, the subsidence declined substantially after $30 \mathrm{Ma}$ and lasted at a slow rate during 30-23 Ma (Fig. 6), which is similar to the characteristics of post-rift subsidence. Nonetheless, considering the strong faulting during 30-21 Ma [see Fig. 8 as well as previous faulting studies (Xie et al. 2007; Zhong 2000; Yin et al. 2010)], this period together with the subsequent fast subsidence period 23-21 Ma (Fig. 6) are classified as part of the syn-rift stage, which may be affected by the opening of the South China Sea and the ridge propagation into the Southwest subbasin to the south of Qiongdongnan Basin (Taylor 1983; Briais et al. 1993).

2. Post-rift slow thermal subsidence during Early-Middle Miocene (21-10.5 Ma). The subsidence rate is around $40 \mathrm{~m} / \mathrm{m} . \mathrm{y}$. and the curve of subsidence rate is very smooth during 21-15.5 Ma and 15.5-10.5 Ma (Fig. 5b) compared with the syn-rift period, which are the characteristics of post-rift thermal subsidence period with a low rate and are classified as the post-rift slow thermal subsidence.

3. Post-rift accelerated subsidence since Late Miocene (10.5-0 Ma). The subsidence rate varies from 40 to $140 \mathrm{~m} / \mathrm{m} . \mathrm{y}$. and increases eastward with the subsidence center locates invariably in the east (BaoDao and ChangChang Sags) (Fig. 5c). During the period $10.5-5.5 \mathrm{Ma}$, there is a slightly rapid subsidence at the west end of the basin $(80 \mathrm{~m} / \mathrm{Ma}$, Fig. $5 \mathrm{c})$ which may be the result of activity along the Red River Fault. In contrast, there is slower subsidence in LeDong Sag, LingShui sag and SongNan Low Uplift at the rate of $40 \mathrm{~m} / \mathrm{m} . \mathrm{y}$. and markedly faster subsidence in the east as large as $140 \mathrm{~m} / \mathrm{m} . \mathrm{y}$. that time (Figs. 5c, 6). In the west, the subsidence rate began to accelerate (60-80 m/m.y.) since 5.5 Ma including LeDong Sag, LingShui Sag and SongNan Low Uplift. In the east, however, the rate keeps the same as $140 \mathrm{~m} / \mathrm{m}$.y. with the 10.5-5.5 Ma during 5.5-0 Ma (Fig. 5c, 6). Generally, during $10.5-0 \mathrm{Ma}$, the subsidence rate curve is very smooth with the amplitude having little oscillation laterally showing the post-rift thermal subsidence features. Although the tectonic subsidence began to accelerate since $5.5 \mathrm{Ma}$ in the west (LeDong Sag, LingShui Sag and SongNan Low Uplift), the accelerated subsidence originated from the beginning of 10.5 $\mathrm{Ma}$ at a high rate in the east in SongNan, BaoDao and ChangChang Sags. Therefore, the period $10.5-0 \mathrm{Ma}$ is considered as the post-rift accelerated subsidence here. 

with six points selected for subsidence analyses (P1 lies in the LeDong Sag, P2 locates in the LingShui Sag, P3 sits on the SongNan Low Uplift, and P4, P5, P6 are in the SongNan, BaoDao and ChangChang Sags respectively)
Fig. 4 Depth section of Line 1

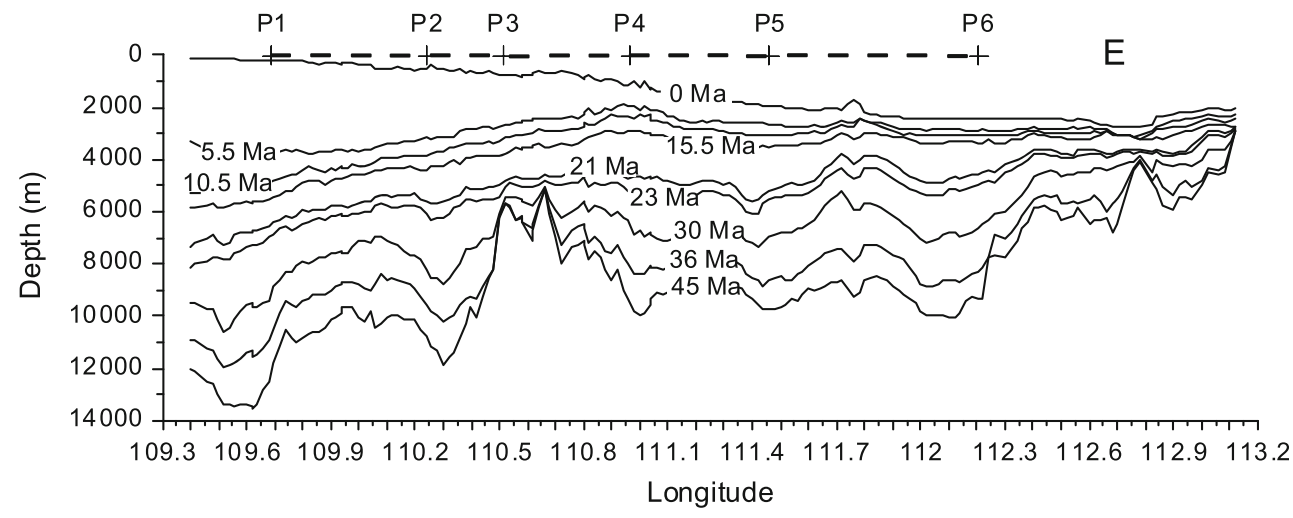

Fig. 5 Unloaded tectonic subsidence rate (EBSR, m/m.y.) along Line1 (location of Line 1 see Fig. 1), Fig. 5a is the synrift tectonic subsidence during Eocene-Oligocene (45-21 Ma), Fig. $5 \mathrm{~b}$ indicates the post-rift slow thermal subsidence during Early-Middle Miocene

(21-10.5 Ma), and Fig. 5c is the Post-rift accelerated subsidence since Late Miocene

(10.5-0 Ma)

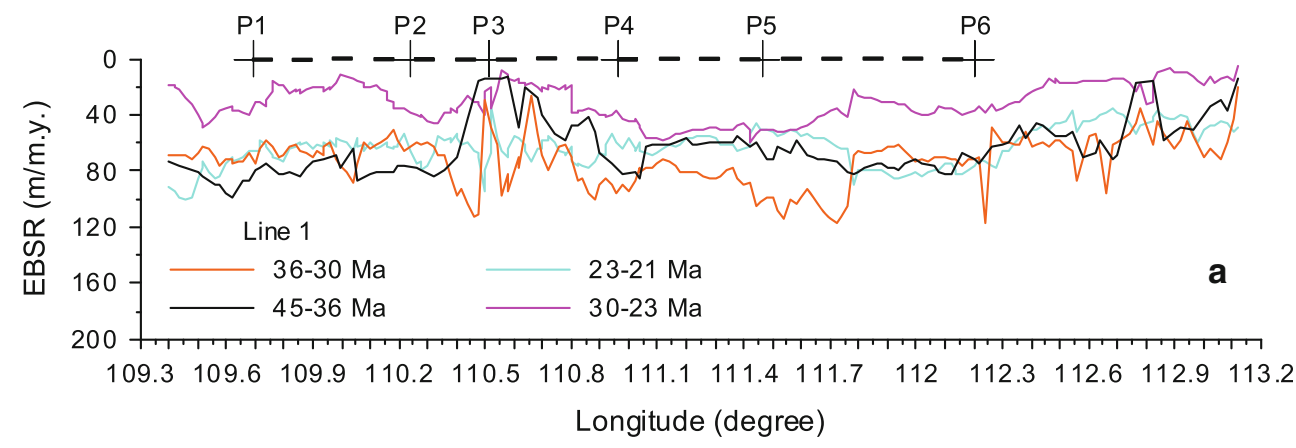

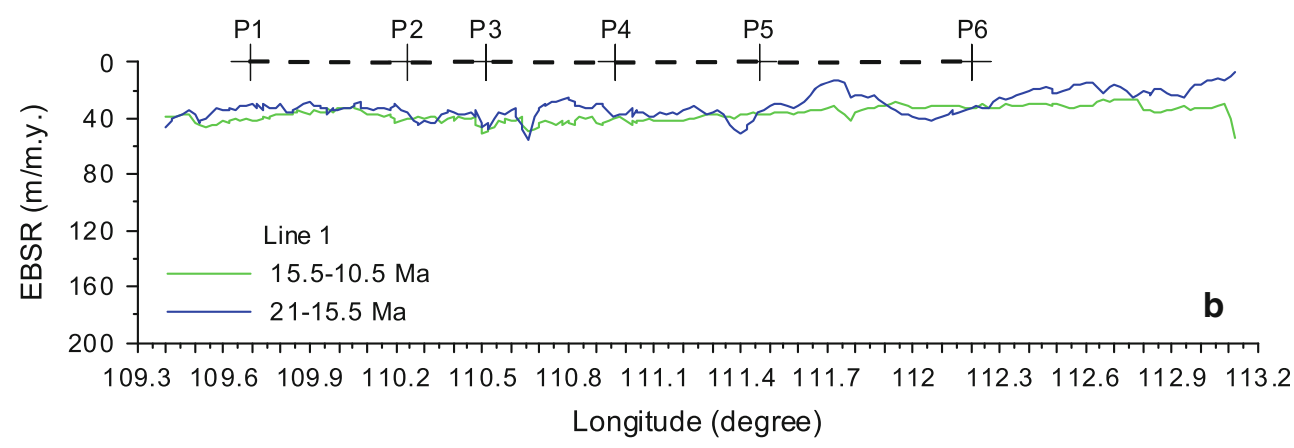

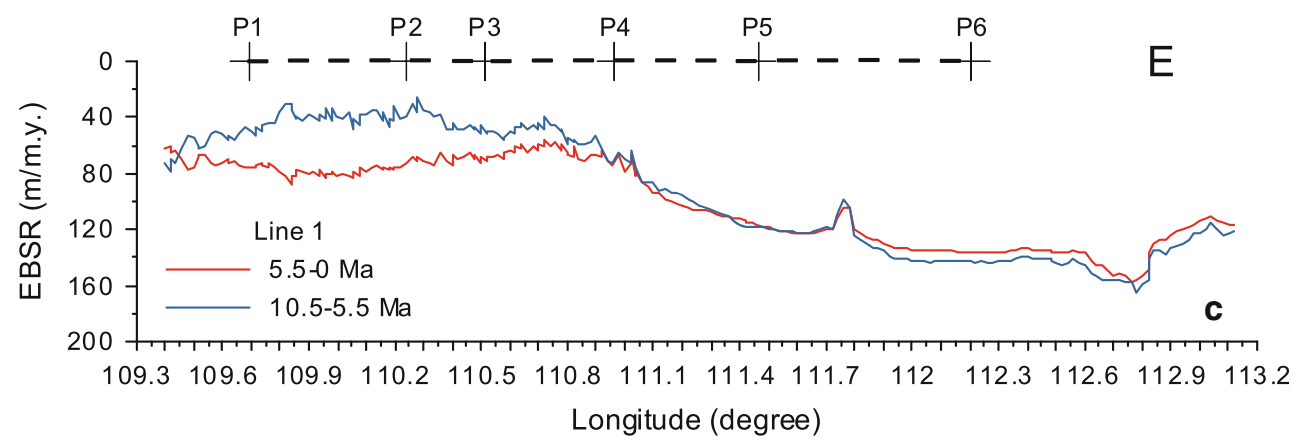

\section{Characteristics of sedimentation in Qiongdongnan Basin}

The sediment thickness of eight strata (45-36, 36-30, 30-23, 23-21, 21-15.5, 15.5-10.5, 10.5-5.5 and 5.5-0 Ma) of Line 1 (Figs. 1, 4) are computed after decompaction during backstripping under the constraint of lithology of five wells (\#1, \#2, \#3, \#4, \#5) in the deepwater area (Fig. 1) with the lithologic parameters for decompaction derived from the Baiyun Sag deepwater in the Pearl River Mouth Basin (Zhao et al. 2011). The calculated sedimentation rates are illustrated in Fig. 7, which can be divided into three stages (45-21, 21-10.5 and 10.5-0 Ma) in consistent with the classification of tectonic subsidence. 
Fig. 6 Unloaded tectonic subsidence rate (EBSR, m/m.y.) histograms of six points along Line 1 (locations of six points see Figs. 1, 4)
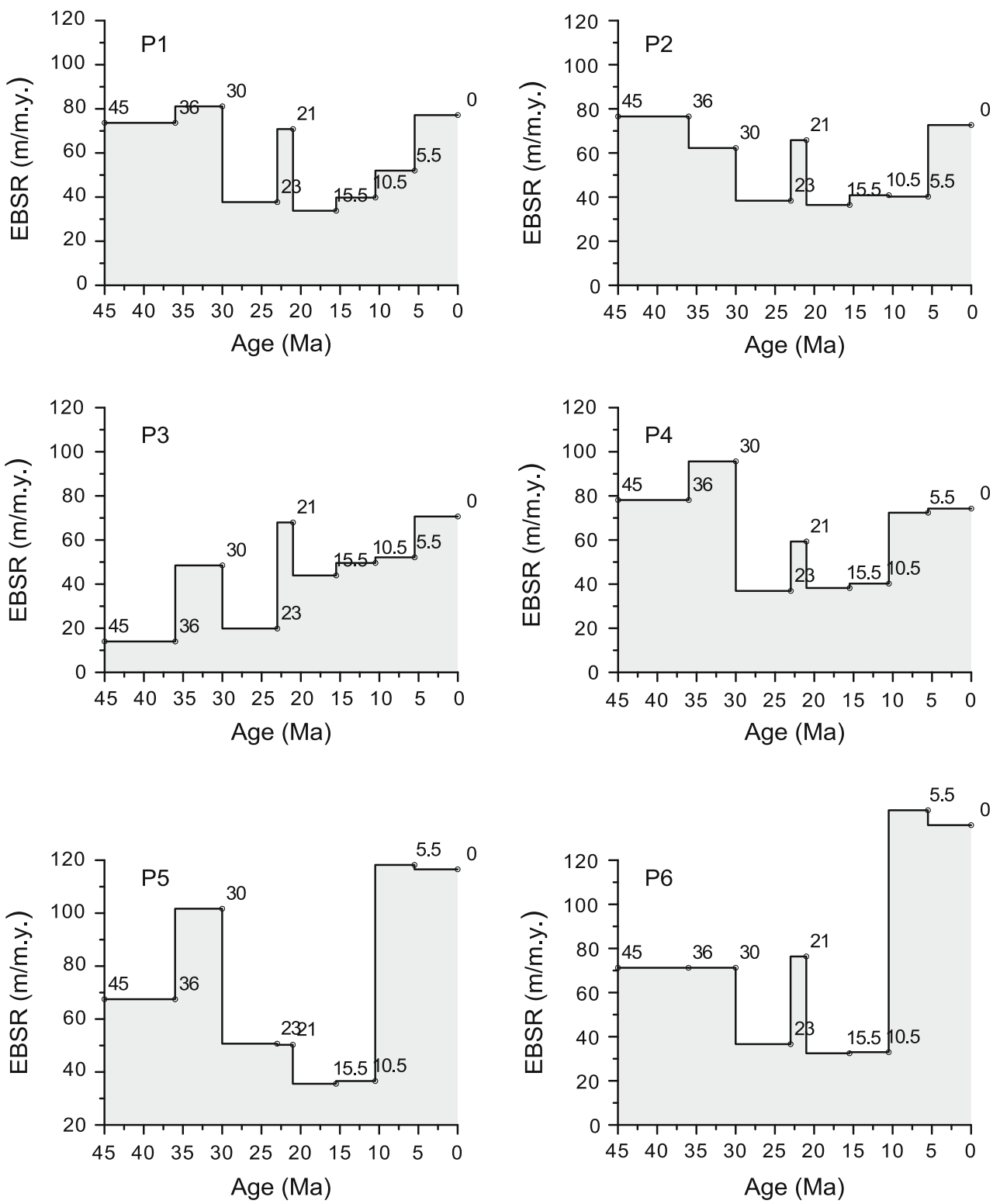

The amplitude of syn-rift sedimentation rate during 45-21 Ma (Fig. 7a) oscillated largely from 0 to $600 \mathrm{~m} / \mathrm{m}$.y., similar to the variation of syn-rift tectonic subsidence in Fig. 5a and affected significantly by the basement topography (Fig. 4), having the depocenters separated by the low uplifts with the low sedimentation rate even erosion beneath SongNan Low Uplift (P3 in Fig. 7a) and the high rate in LeDong, LinShui, SongNan, BaoDao and ChangChang Sags.

The post-rift sedimentation during 21-10.5 Ma (Fig. 7b) is characterized by the smooth curve of sedimentation rate with almost constant value of $400 \mathrm{~m} / \mathrm{m} . \mathrm{y}$. in $21-15.5 \mathrm{Ma}$ and $100 \mathrm{~m} / \mathrm{m} . \mathrm{y}$. in $15.5-10.5 \mathrm{Ma}$.

The post-rift sedimentation during 10.5-0 Ma (Fig. 7c) is characterized by the smooth curve of sedimentation rate and by the migration of depocenter to the west in the
LeDong, LingShui Sags. The sedimentation rate increases dramatically westwards, from 0 to $600 \mathrm{~m} / \mathrm{m} . \mathrm{y}$. in 10.5-5.5 Ma and from 0 to 800 m.y. in 5.5-0 Ma, which are contrary to the tectonic subsidence in Fig. $5 \mathrm{c}$.

\section{Faulting analyses}

Normal basement faulting, the widespread structural styles in the upper crust caused by tectonic tensile forces, indicates the brittle crust deformation during stretching. 48 seismic lines from CNOOC across Qiongdongnan Basin (Fig. 1) are selected and interpreted, from which the active faults (determined from the different strata thickness between the hangingwall and footwall) of eight phases during 45-36, 36-30, 30-23, 23-21, 21-15.5, 15.5-10.5, 
Fig. 7 Illustration of sedimentation rates along Line 1 (location of Line 1 see Fig. 1).

Figure $7 \mathrm{a}$ is the syn-rift sedimentation rate during Eocene-Oligocene (45-21 Ma), Fig. $7 b$ is the post-rift sedimentation rate during EarlyMiddle Miocene (21-10.5 Ma), and Fig. $7 \mathrm{c}$ is the post-rift sedimentation rate since Late Miocene (10.5-0 Ma)
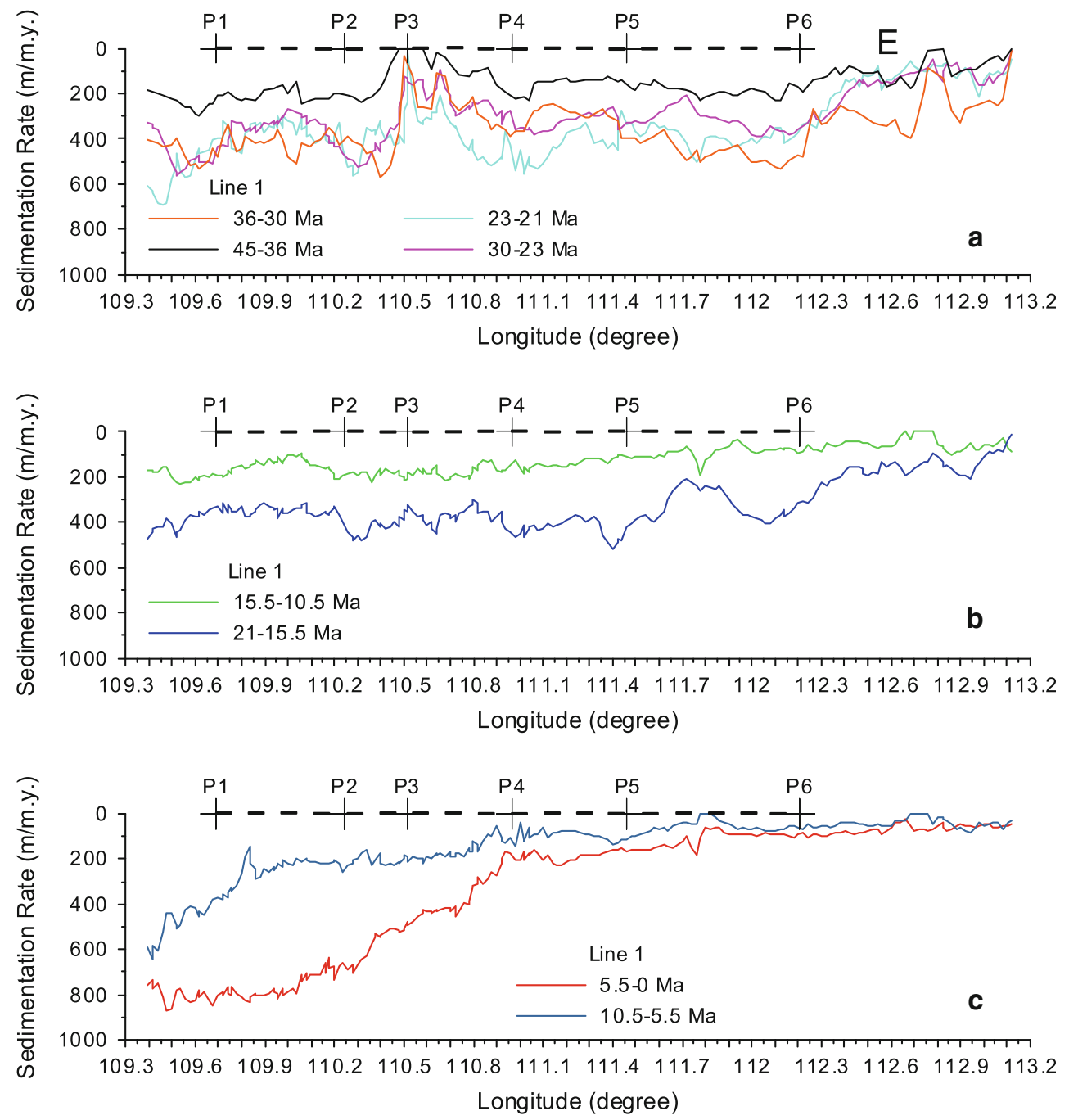

10.5-5.5 and 5.5-0 Ma are identified respectively. And the identified numbers of active faults of each phase are illustrated in Fig. 8a.

The fault growth rate, defined as the difference in thickness between the hangingwall and footwall of the same strata per unit time interval (Formula 9), was proposed by Zhao (1989) and Li et al. (2000), which are used to analyze the faulting intensity of active faults of eight phases (45-36, $36-30,30-21,21-15.5,15.5-10.5,10.5-5.5,5.5-1.6$ and 1.6-0 Ma) in the Qiongdongnan Basin. The calculated results of fault growth rate are illustrated in Fig. 8b.

Fault Growth Rate $=\Delta H / \Delta t=\left(H_{\text {hangingwall }}-H_{\text {footwall }}\right) / \Delta t$

where $H_{\text {hangingwall }}, H_{\text {footwall }}, \Delta H$ are the thickness of haningwall, footwall and the difference between them of the same strata, and $\Delta t$ is the time interval of each strata.

There is a dramatically decrease both in the numbers of active faults (Fig. 8a) and fault growth rate (Fig. 8b) since $21 \mathrm{Ma}$. The numbers of active faults identified from 48 seismic lines (Fig. 1) are between 485 and 366 before $21 \mathrm{Ma}$ except 45-36 Ma, and then dramatically decrease to 198 in 21-15.5 Ma, then gradually decline to about 80 to present (Fig. 8a). The fault growth rate is greater than $60 \mathrm{~m} / \mathrm{m}$.y. before $21 \mathrm{Ma}$ and declines substantially to $20 \mathrm{~m} / \mathrm{m}$.y. after $21 \mathrm{Ma}$ (Fig. 8b). The results of identified numbers of active faults (Fig. 8a) and faults growth rate (Fig. 8b) of the selected 48 seismic lines (Fig. 1) across the Qiongdongnan Basin show that the Qiongdongnan Basin experienced a fault-controlled basin phase and subsequently a sag phase bounded by $21 \mathrm{Ma}$, which indicates that the brittle crust deformation mainly happened during 45-21 Ma and little crustal extension took place since $21 \mathrm{Ma}$.

\section{The dynamic mechanism of the post-rift accelerated subsidence}

The post-rift accelerated tectonic subsidence since Late Miocene in Qiongdongnan Basin is substantially deviates 
Fig. 8 Faulting analyses of eight phases (45-36, 36-30, $30-23,23-21,21-15.5$, $15.5-10.5,10.5-5.5$ and $5.5-0 \mathrm{Ma}$ ), Fig. $8 \mathrm{a}$ is the numbers of active faults identified from 48 seismic lines (Fig. 1) and Fig. $8 \mathrm{~b}$ is the average fault growth rate $(\mathrm{m} /$ m.y.)

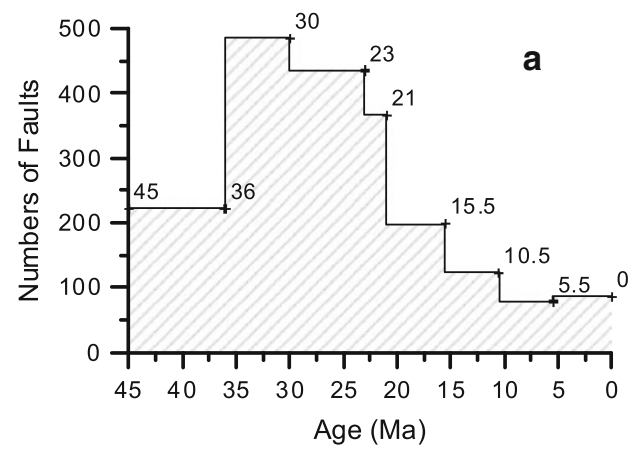

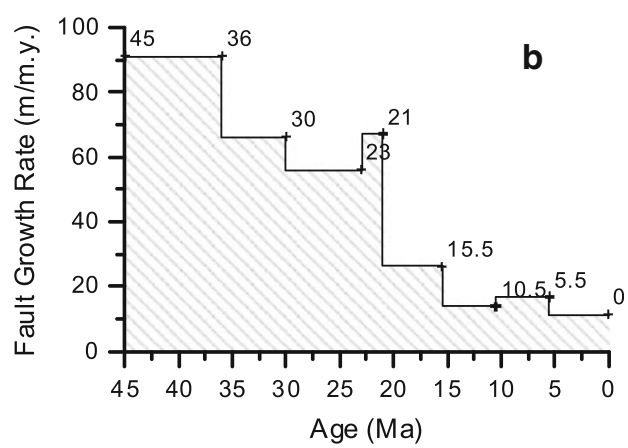

from the slow thermal subsidence of typical Atlantic continental margins (Steckler and Watts 1978; Mckenzie 1978), and can not be explained by the simple pure model proposed by McKenzie (1978). Faulting analyses above (Fig. 8) and previous studies (Zhong; Xie et al. 2007; Yin et al. 2010) show that little faulting occurred since Late Miocene, implying that there is no active brittle crustal extension since that time. Other research have demonstrated the stretching of upper brittle crust is less than the whole crust (Clift et al. 2001, 2002; Zhang et al. 2010; Lei et al. 2013), meaning that the lower ductile crust thinned more than the upper brittle crust, although the time of this lower crustal stretching is not known. The depthdependent lithosphere stretching calculation method, proposed by Davis and Kusznir (2004), considered all the post-rift subsidence as thermal subsidence and Kusznir et al. (2005, 2007)argued that the depth-dependent stretching occurred at the time of the continental lithosphere breakup. However, these theories can not be applied to the Qiongdongnan Basin because the accelerated subsidence is known to be in the postrift period. Considering all above, the lower ductile crust may thin in the post-rift period in Qiongdongnan Basin. Based on this presumption, a new model of basin development and evolution is built and tested.

\section{Post-rift lower crust thinning model}

As McKenzie (1978) proposed, the evolution of a rift basin can be divided into two stages, syn-rift and post-rift. In the syn-rift, there is stretching of continental lithosphere associated with block faulting, crustal and mantle thinning, subsidence, upwelling of asthenosphere and an enhanced temperature gradient. During the post-rift phase, the lithosphere thickens by heat conduction to the surface and further slow subsidence occurs without faulting.

The new model will take the lower, ductile crust thinning process into consideration during the post-rift stage while other conditions and assumptions remain the same as for the McKenzie's model. During the post-rift period, the lower ductile crust thinning rate is assumed to be $\gamma \mathrm{km} / \mathrm{m}$.y. which is responsible for the post-rift accelerated subsidence caused by lower crust thinning without faulting. This model is tested by the gravity data of Lines 2, 3 and 4 which intersect with Line 1 at A, B and C, respectively (locations are shown in Fig. 1).

\section{Syn-rift unloaded tectonic subsidence}

The lithospheric stretching in the syn-rift is assumed to be instantaneous and uniform. McKenzie (1978) offered the syn-rift water-loaded basin subsidence formula. After modification, the syn-rift water and sediment unloaded tectonic subsidence $\left(S_{r}\right)$ is obtained by Formula 10 .

$S_{r}=\frac{a\left[\left(\rho_{m 0}-\rho_{c 0}\right) \frac{t_{c}}{a}\left(1-\alpha T_{1} \frac{t_{c}}{a}\right)-\frac{\alpha T_{1} \rho_{m 0}}{2}\right](1-1 / \beta)}{\rho_{m 0}\left(1-\alpha T_{1}\right)}$

where $a$ is the thickness of the lithosphere and $t_{c}$ is the initial crustal thickness, $\beta$ the lithosphere stretching factor, $\rho_{m 0}$ the density of mantle, $\rho_{c 0}$ the density of continental crust both at $0{ }^{\circ} \mathrm{C}, \alpha$ the thermal expansion coefficient of both the mantle and the crust, and $T_{1}$ the temperature of the asthenosphere.

\section{Post-rift unloaded tectonic subsidence}

Assuming that the lower ductile crust thinning occurs during the post-rift period, this would cause the subsidence to occur by crust thinning without faulting. As the effect of ductile crust thinning on the post-rift thermal subsidence is ignored, the post-rift unloaded tectonic subsidence $\left(S_{p}\right)$ (Formula 11) is considered to consists of post-rift thermal subsidence $\left(S_{\text {thermal }}\right)$ solely depending on the lithospheric stretching during the syn-rift period and Post-rift ductile crust thinning subsidence $\left(S_{\text {thin }}\right)$.

$S_{p}=S_{\text {thermal }}+S_{\text {thin }}$

\section{Post-rift thermal subsidence}

The post-rift unloaded thermal subsidence $\left(S_{\text {thermal }}\right)$ depends only on the amount of syn-rift lithosphere stretching, and Formulas 12 and 13 show how this is calculated after modification based on McKenzie (1978). 


$$
\begin{aligned}
e 1(t)= & \frac{a \rho_{m 0} \alpha T_{1}}{\rho_{m 0}}\left\{\frac{4}{\pi^{2}} \sum_{m=0}^{\ominus} \frac{1}{(2 m+1)^{2}}\right. \\
& {\left.\left[\frac{\beta}{(2 m+1) \pi} \sin \frac{(2 m+1) \pi}{\beta}\right] \exp \left(-(2 m+1)^{2} \frac{t}{\tau}\right)\right\} }
\end{aligned}
$$

$S_{\text {thermal }}=e 1(0)-e 1(t)$

where $e 1(t)$ is the elevation above the final depth to which the upper surface of the lithosphere sinks, and $\tau$ is thermal contraction constant, approximately is $62.8 \mathrm{Ma}$.

\section{Post-rift lower crust thinning subsidence}

The lower ductile crust thinning rate is assumed to be $\gamma$ $\mathrm{km} / \mathrm{m}$.y. which is responsible for the post-rift accelerated subsidence caused by crust thinning in the absence of faulting. The formula for the post-rift lower crust thinning subsidence $\left(S_{\text {thin }}\right)$ is given by Formula 14 .

$S_{\text {thin }}=\left(1-\frac{\rho_{d c}}{\rho_{m 0}\left(1-\alpha T_{1}\right)}\right) \times \int_{0}^{t} \gamma d t$

where, $\rho_{d c}$ is the average ductile crust density.

The amount of post-rift lower crust thinning

Based on the new model, the amount of post-rift lower crust thinning can be computed from the tectonic subsidence backstripped along Line 1. Firstly, the post-rift subsidence caused by crust thinning should be separated from the post-rift subsidence driven by thermal process in the mantle lithosphere. In order to figure out the post-rift thermal subsidence, the syn-rift lithosphere stretching factor must be calculated from the syn-rift tectonic subsidence. The initial crustal thickness is set to $32 \mathrm{~km}$ (Zhang et al. 2010), and other parameters are listed in Table 1. The syn-rift lithosphere stretching factor is calculated by Formula 10 and illustrated as a red line in Fig. 9. The syn-rift stretching factor varies between 1.4 and 3.5 with the smallest stretching factor of 1.4 on the SongNan Low Uplift and the largest stretching factor 3.5 in the SongNan and BaoDao Sags. The post-rift thermal subsidence is computed by Formulas 12 and 13 with the result shown in red line in Fig. 10. The post-rift thermal subsidence is 200-600 m. The black line in Fig. 10 is the total post-rift subsidence and the blue line is the post-rift subsidence caused by crustal thinning, which is derived by subtracting the post-rift thermal subsidence from the total post-rift subsidence. The post-rift crustal thinning subsidence is 500-1,500 $\mathrm{m}$ and gradually increases from west to east. It is obviously that the post-rift crustal thinning subsidence on SongNan Low Uplift $(900 \mathrm{~m})$ is greater than that in neighboring sags $(600 \mathrm{~m})$ on both sides. Secondly, the
Table 1 Values of parameters used (mostly taken from McKenzie (1978)

$$
\begin{aligned}
& \hline a=125 \mathrm{~km} \\
& t_{c}=32 \mathrm{~km} \\
& \rho_{m 0}=3,330 \mathrm{~kg} \mathrm{~m}^{-3} \\
& \rho_{c 0}=2,800 \mathrm{~kg} \mathrm{~m}^{-3} \\
& \rho_{d c}=2,700 \mathrm{~kg} \mathrm{~m}^{-3} \\
& \rho_{w}=1,030 \mathrm{~kg} \mathrm{~m}^{-3} \\
& \alpha=3.28 \times 10^{-5}{ }^{\circ} \mathrm{C}^{-1} \\
& T_{1}=1,333{ }^{\circ} \mathrm{C} \\
& \tau=62.8 \mathrm{My}
\end{aligned}
$$

amount of post-rift ductile crust thinning can be calculated by Formula 14 when the post-rift crustal thinning subsidence is known. The lateral variation in the degree of postrift crust thinning is illustrated by a black line in Fig. 11. The amount of post-rift crust thinning is $3-9 \mathrm{~km}$ and generally increases eastwards, similar to the subsidence driven by post-rift crustal thinning. The amount of crust thinning on SongNan Low Uplift $(6 \mathrm{~km})$ is greater than that in nearby sags $(4 \mathrm{~km})$. The red line in Fig. 11 indicates the initial crustal thickness with value of $32 \mathrm{~km}$, the blue line is the crustal thickness after syn-rift stretching, and the green line is the remaining crustal thickness after syn-rift stretching and post-rift lower crust thinning.

The remaining crustal thickness changes dramatically along Line 1. The thinnest crust thickness is about $2.5 \mathrm{~km}$ in the BaoDao and ChangChang Sag and the thickest crust is approximately $18 \mathrm{~km}$ at the SongNan Low Uplift and to the southeast of ChangChang Sag. Lines 2, 3 and 4 intersect with Line 1 at points $\mathrm{A}, \mathrm{B}$ and $\mathrm{C}$ respectively (locations are shown in Fig. 1), and for which the crustal thicknesses have been modeled by gravity data (Qiu et al. 2013; Wang et al. 2013) which can be used to test the post-rift lower crust thinning model. The crustal structures of lines 2, 3 and 4 are presented in Fig. 12. As the crustal thickness of points A, B and C are projected onto Line 1 in Fig. 11, the remaining crustal thickness and the crustal thickness modeled by gravity fit surprisingly well. This observation strongly supports the concept of post-rift lower crust thinning.

The amount of post-rift crustal thinning for the post-rift slow thermal subsidence phase (21-10.5 Ma) and post-rift accelerated subsidence phase $(10.5-0 \mathrm{Ma})$ is illustrated in Fig. 13 with the post-rift crust thinning rate shown in Fig. 14.

It is obviously that there is little post-rift crust thinning during the post-rift slow thermal subsidence (21-10.5 Ma) except the SongNan Low Uplift with the crust thinned from the very beginning of the post-rift stage at a high rate of $0.2 \mathrm{~km} / \mathrm{m}$.y. and increased to $0.3 \mathrm{~km} / \mathrm{m}$.y. since $10.5 \mathrm{Ma}$. The post-rift crust thinning mainly occurred during the post-rift accelerated subsidence phase (10.5-0 Ma) with the amount of crust thinning increased from $3 \mathrm{~km}$ in the west (LeDong Sag, LingShui Sag, SongNan Low Uplift and SongNan Sag) abruptly to $9 \mathrm{~km}$ in the east (BaoDao 

tectonic subsidence (black line) and syn-rift lithospheric stretching factor- $\beta$ (red line) calculated from the syn-rift unloaded tectonic subsidence using the Formula 10
Fig. 9 Syn-rift unloaded
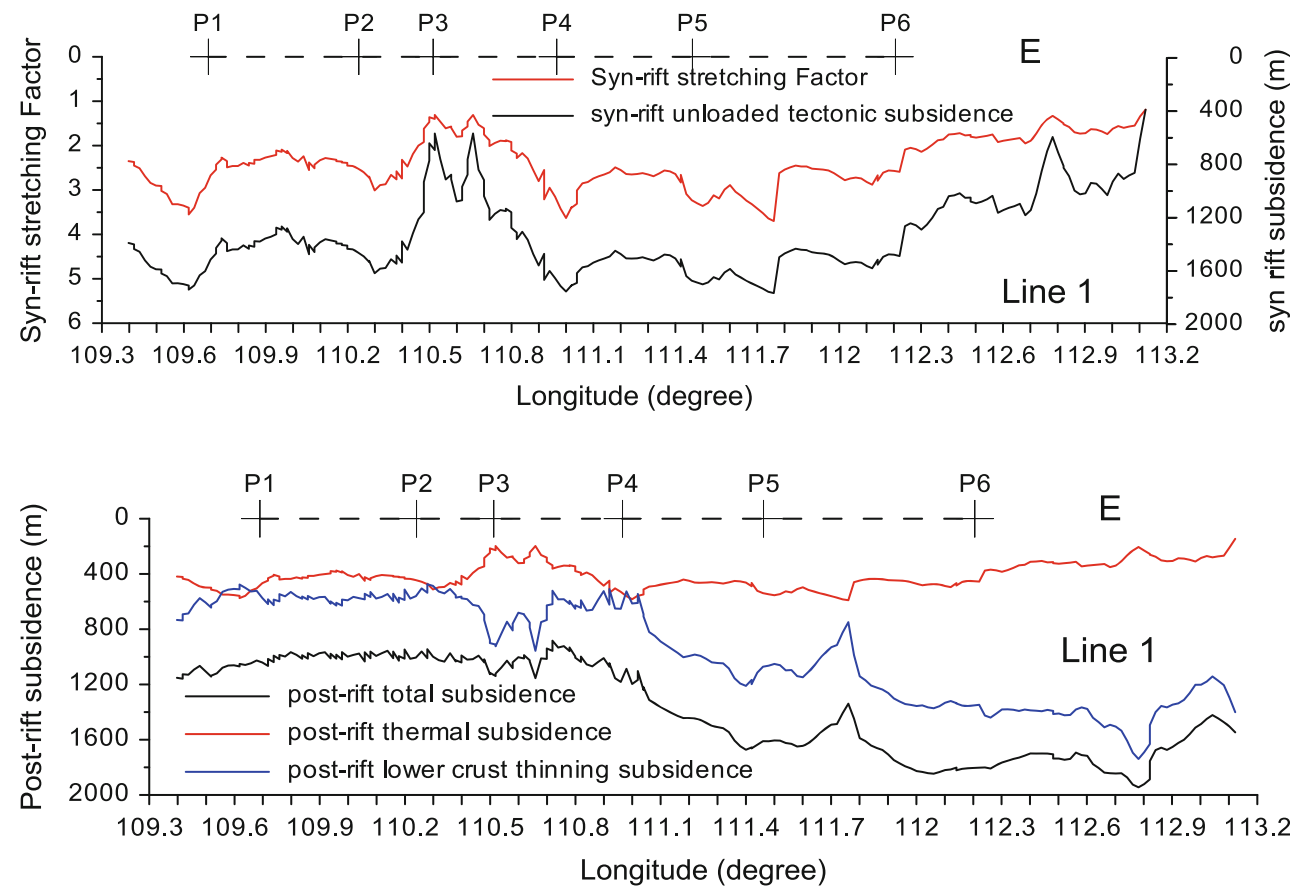

Fig. 10 Post-rift total subsidence (black line), the sum of post-rift thermal subsidence (red line) and post-rift lower crustal thinning subsidence

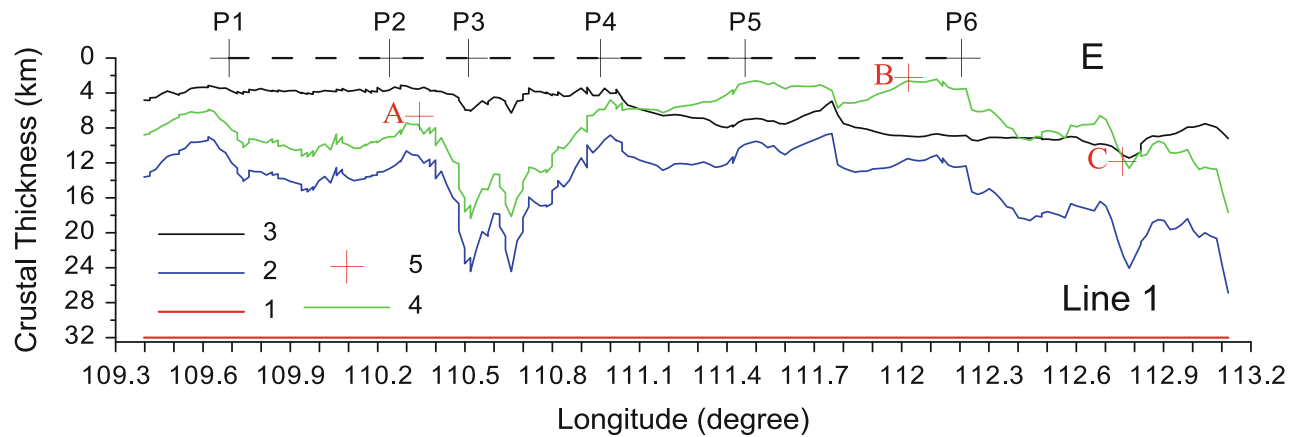

Fig. 11 Illustration of crustal thickness, 1-initial crustal thickness, 2-crustal thickness after syn-rift stretching, 3-the amount of post-rift crust thinning, 4-the remaining crust thickness after syn-rift crust

Sag, ChangChang Sag) and the rate changed accordingly from 0.3 to $0.8 \mathrm{~km} / \mathrm{m}$.y.. The post-rift lower crust thinning subsidence caused by the amount of post-rift lower crust thinning is responsible for the post-rift accelerated subsidence since $10.5 \mathrm{Ma}$.

The depth-dependent crust thinning in Qiongdongnan Basin

The upper crust stretching factor keeps the same as the synrift lithosphere stretching factor (red line in Fig. 9) because there is little faulting in the post-rift phase (Fig. 8). However, the whole crust stretching factor will be larger than that of upper crust when post-rift lower ductile crust thinning happens, as predicted by the post-rift lower crust thinning model. The whole crust stretching factor is calculated from the initial crust thickness (red line in Fig. 11) stretching and post-rift crust thinning, 5-inversed crust thickness by Gravity (A, B, C are the intersections of Lines 2, 3 and 4 with Line 1, respectively)

and the remaining crust thickness after syn-rift crust stretching and post-rift crust thinning (green line in Fig. 11). The stretching factor of the upper crust and the whole crust are compared along Line 1 in Fig. 15. The upper crust stretching factor varies between 2 and 3 while that of the whole crust varies between 2 and 12 with the largest discrepancy between them occurring in BaoDao and ChangChang Sags. The post-rift crust thinning model can account for the depth-dependent crust thinning in Qiongdongnan Basin.

\section{Discussions}

The post-rift lower crust thinning model can explain the post-rift accelerated subsidence and the depth-dependent crust thinning in Qiongdiongnan Basin, where the lower 
Fig. 12 Crustal structure of line 2 , line 3 , line 4 inversed by gravity anomaly (Qiu et al. 2013; Wang et al. 2013) ( $A, B$, $C$ are the intersections of Lines 2, 3 and 4 with Line 1, respectively)
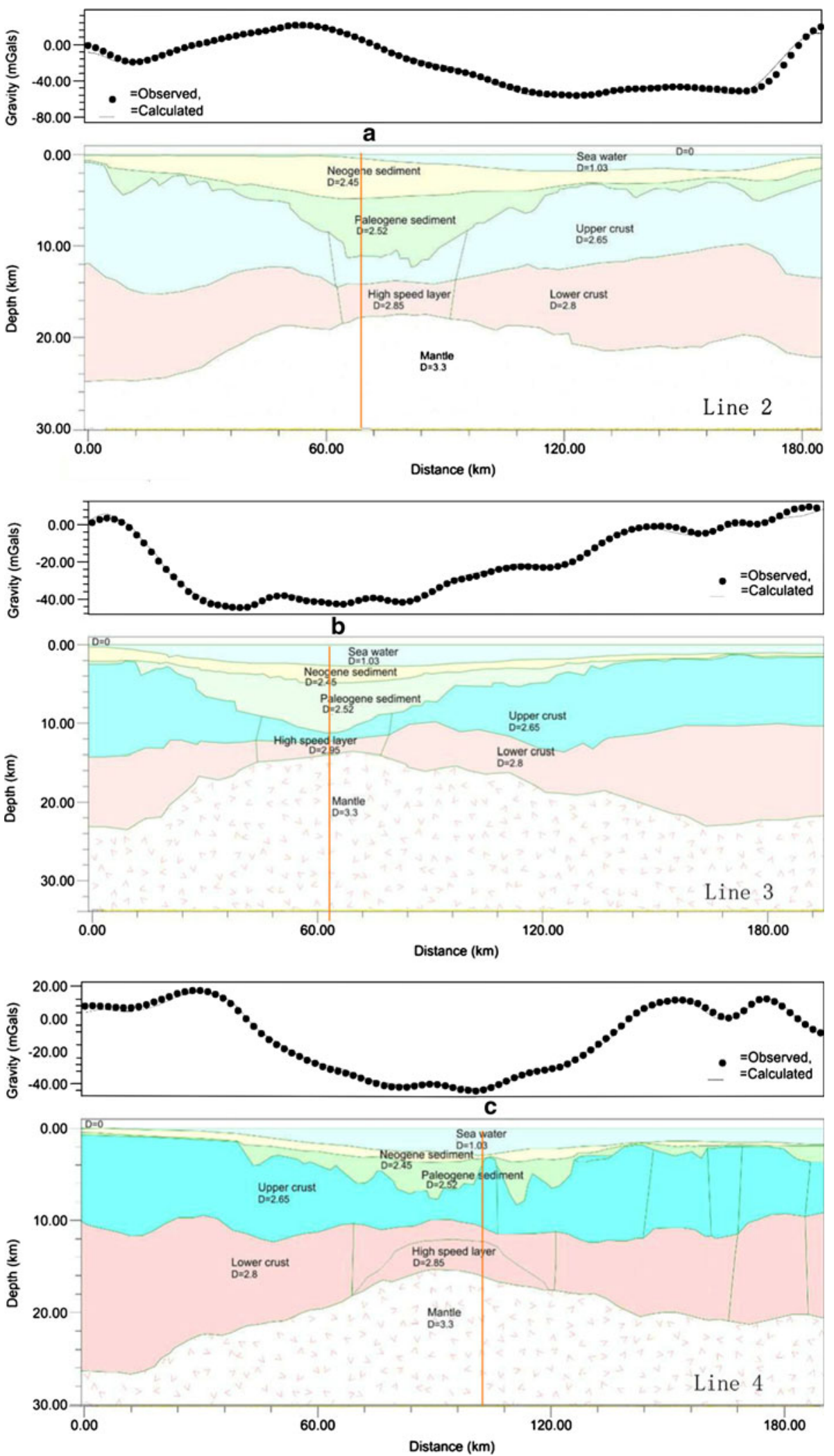

crust is rather weak with the viscosities of $10^{19}-10^{18} \mathrm{~Pa} \mathrm{~s}$ (Clift et al. 2002). However, what confuses us is what caused the post-rift lower ductile crust thinning? Was the post-rift crust thinning caused by the lower ductile crust flow induced by the rapid sedimentation proposed by Westaway (2002)? According to the theory of Westaway 
Fig. 13 The amount of post-rift lower crust thinning of two periods $(21-10.5$ and 10.5-0 Ma) of Line 1

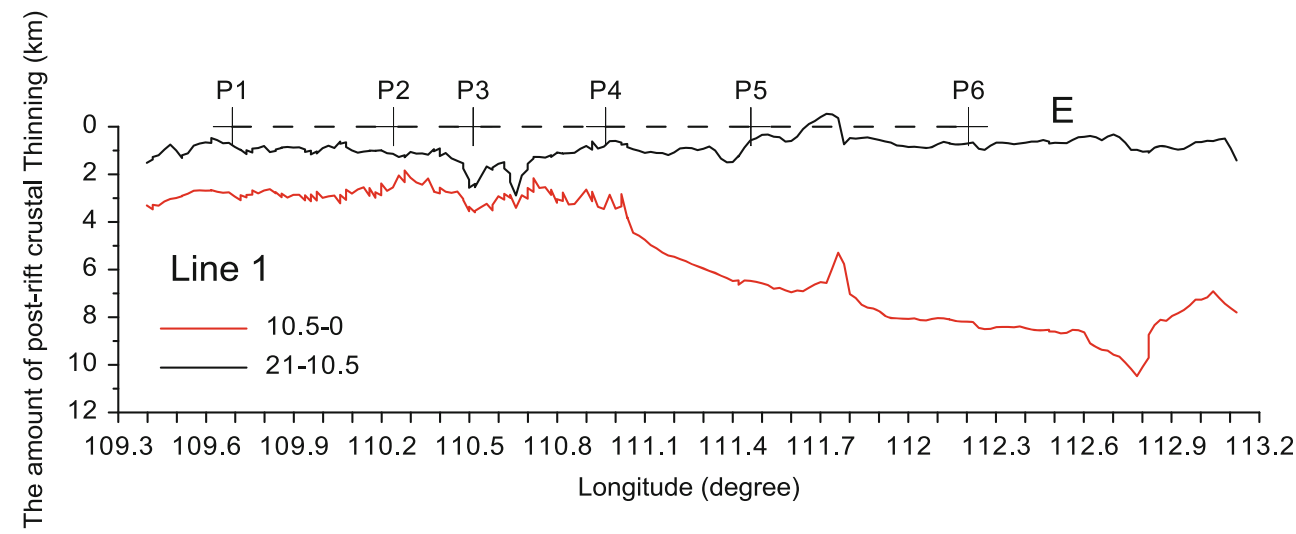

Fig. 14 Post-rift lower crust thinning rate of two periods (21-10.5 and 10.5-0 Ma) of Line 1
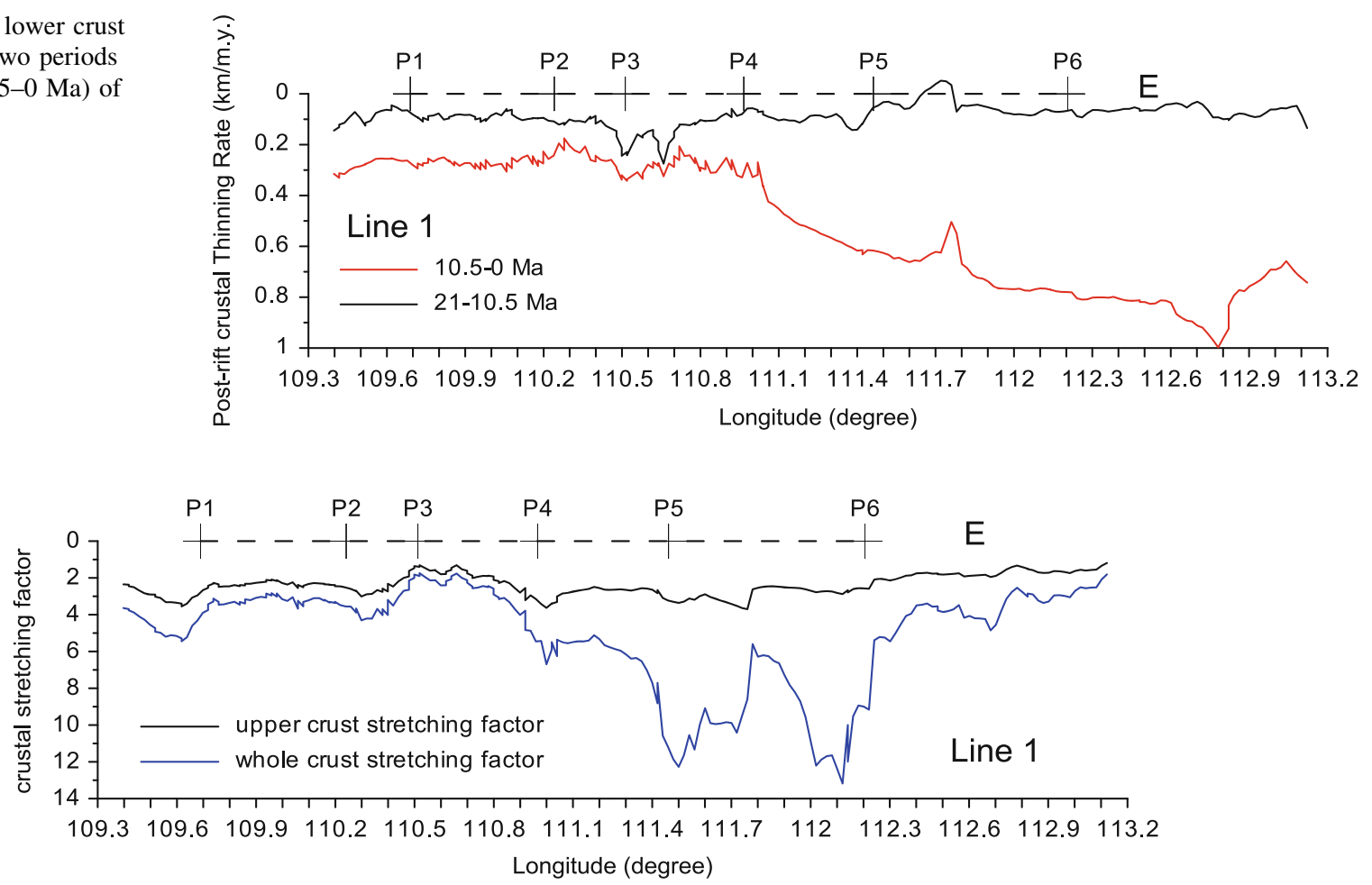

Fig. 15 The depth-dependent crust thinning of Qiongdongnan Basin, the black line is upper crust stretching factor, also the syn-rift lithospheric stretching factor, calculated from the syn-rift unloaded tectonic subsidence (Fig. 9) and the blue line is the whole crust

stretching factor, the ratio of initial crust thickness (red line in Fig. 11) and the remaining crust thickness after syn-rift crust stretching and post-rift crust thinning (green line in Fig. 11)

et al. 2010), and this could be the cause of post-rift crust thinning in the Qiongdongnan Basin? We favor this as the most likely explanation at the present time.

\section{Conclusions}

1. A 1-D unloaded tectonic subsidence (air-loaded tectonic subsidence) model is proposed and applied in the Qiongdongnan Basin. The unloaded tectonic subsidence is the true tectonic subsidence without any load induced isostatic subsidence, making the concept of tectonic 
subsidence clear and the analysis of dynamic mechanism easier.

2. The evolution of tectonic subsidence in Qiongdongnan Basin can be divided into three stages, that is, syn-rift rapid subsidence (Eocene-Oligocene) with the subsidence rate of $20-100 \mathrm{~m} / \mathrm{m}$.y., post-rift slow thermal subsidence (early-middle Miocene) around $40 \mathrm{~m} / \mathrm{m} . \mathrm{y}$., and post-rift accelerated subsidence (since late Miocene) $40-140 \mathrm{~m} / \mathrm{m} . \mathrm{y}$.. The accelerated subsidence mostly occurred in the east in BaoDao and ChangChang Sags of Qiongdongnan Basin, which is contrary to the sedimentation with the depocenter migrated to the west in the LeDong, LingShui Sags since late Miocene.

3. Results of faulting analyses from 48 seismic lines across Qiongdongnan Basin show that the Qiongdongnan Basin experienced a fault-controlled basin phase and subsequently a sag phase bounded by $21 \mathrm{Ma}$, which indicates that the brittle crust deformation mainly occurred during 45-21 Ma and little crustal extension took place after $21 \mathrm{Ma}$.

4. The post-rift lower crust thinning model is proposed and can explain the post-rift accelerated subsidence and depth-dependent crust thinning, which is consistent with gravity data.

Acknowledgments The manuscript was reviewed by Pro. Clift, Pro. $\mathrm{Xie}$, and Lei $\mathrm{PhD}$, and their valuable suggestions help us both in English language and in depth to improve the quality of the paper. This research was supported by the National Key Basic Research and Development Program (973 Program) (No. 2009CB219401), the Major National Science and Technology Programs (No. 2011ZX05025-00201) and CAS key Lab of Marginal Sea Geology, South China Sea Institute of Oceanology (No. MSGL13-06).

Open Access This article is distributed under the terms of the Creative Commons Attribution License which permits any use, distribution, and reproduction in any medium, provided the original author(s) and the source are credited.

\section{References}

Bai D, Unsworth MJ, Meju MA, Ma X, Teng J, Kong X, Sun Y, Sun J, Wang L, Jiang C, Zhao C, Xiao P, Liu M (2010) Crustal deformation of the eastern Tibetan plateau revealed by magnetotelluric imaging. Nature 3:358-362

Briais A, Patriat P, Tapponnier P (1993) Updated interpretation of magnetic anomalies and sea-floor spreading stages in the South China Sea: implications for the Tertiary tectonics of Southeast Asia. J Geophys Res 98:6299-6328

Clark MK, Royden LH (2000) Topographic ooze: building the eastern margin of Tibet by lower crustal flow. Geology 28(8):703-706. doi:10.1130/0091-7613(2000)28<703:Tobtem >2.0.Co;2

Clift P, Lin J, Party OLS (2001) Patterns of extension and magmatism along the continent-ocean boundary, South China margin. Geol Soc Lond Spec Publ 187:489-510
Clift P, Lin J, Barckhausen U (2002) Evidence of low flexural rigidity and low viscosity lower continental crust during continental break-up in the South China Sea. Mar Pet Geol 19:951-970

Davis M, Kusznir N (2004) Depth-dependent lithospheric stretching at rifted continental margins. Proceedings of national science foundation rifted margins theoretical institute. Columbia University Press, New York, pp 92-137

Haq BU, Hardenbol J, Vail PR (1987) Chronology of fluctuation sealeavel since the Triassic (250 million years to present). Science 25:1156-1167

Harrison TM, Wenji C, Leloup PH, Ryerson FJ, Tapponnier P (1992) An early Miocene transition in deformation regime within the Red River Fault zone, Yunnan, and its significance for IndoAsian tectonics. J Geophys Res Solid Earth 97(B5):7159-7182

Kusznir NJ, Karner GD (2007) Continental lithospheric thinning and breakup in response to upwelling divergent mantle flow: application to the Woodlark, Newfoundland and Iberia margins. Geol Soc Lond Spec Publ 282:389-419

Kusznir NJ, Hunsdale R, Roberts AM, Team i (2005) Timing and magnitude of depth-dependent lithosphere streching on the southern Lofoten and northern Voring continental margins offshore mid-Norway: implications for subsidence and hydrocarbon maturation at volcanic rifted margins. In: AGV Dore, BA (editor), Petroleum Geology: North-West Europe and Global Perspectives-Proceedings of the 6th Petroleum Geology Conference Petroleum Geology Conferences Ltd Published by the Geological Society, London, pp 767-783

Lei C, Ren JY, Pei JX et al (2011) Tectonic framework and multiple episode tectonic evolution in Deepwater Area of Qiongdongnan Basin, Northern continetnal margin of South China Sea. Earth Sci J China Uni Geosci (in Chinese) 36(1):151-162

Lei C, Ren JY, Tong DJ (2013) Geodynamics of the ocean-continent transition zone, northern margin of the South China Sea: implications for the opening of the South China Sea. Chin J Geophys (in Chinese) 56(4):1287-1299

Li ST, Lin CS, Zhang QM et al (1998) Episodic rifting of northern continental maggin of South China Sea Since $10 \mathrm{Ma}$ (in Chinese). Chin Sci Bull 43(8):797-810

Li QY, Luo FZ, Miao CZ (2000) Research on fault activity ratio and its application (in Chinese). Duankuai Youqitian 7(2):15-17

Li XY, Zhong ZH, Dong WL et al (2006) Paleogene rift structure and its dynamcs of Qiongdongnan basin (in Chinese). Petrol Exp Dev 33(6):713-721

Li JB, Ding WW, Gao JY et al (2011) Cenozoic evolution model of the sea-floor spreading in South China Sea: new constraints from high resolution geophysical data (in Chinese). Chin J Geophys 54(12):3004-3015

Li YM, Shi XB, Xu HL et al (2012) Temporal and spatial distribution of tectonic subsidence and discussion on formation mechanism of anomalous post-rift tectonic subsidence in the Qiongdongnan Basin (in Chinese). J Jilin Univ (Earth Science Edition) 41(1):47-57

Mckenzie D (1978) Some remarks on the development of sedimentary basins. Earth Planet Sci Lett 40:25-30

Qiu N, Sun Z, Wang Z, Liu J, Zhou D, Wang Z, Sun Z (2013) Geophysical investigations of crusta-scale structural model of the Qiongdongnan Basin, Northern South China Sea. Mar Geophys Res. doi:10.1007/s11001-013-9182-8

Ru K, Pigott JD (1986) Episodic rifting and subsidence in the South China Sea. Am Assoc Petrol Geol Bull 70(9):1136-1155

Sclater JG, Christie PAF (1980) Continental stretching: an explanation of the post-mid-cretaceous subsidence of the Central North Sea basin. J Geophys Res 85(37):3711-3739

Song Y, Zhao CY, Zhang GC et al (2011) Reserch on tectono-thermal modeling for Qiongdongnan Basin and Pearl River Mouth Basin 
in the northern South China Sea (in Chinese). Chin J Geophys 54(12):3057-3069

Steckler M, Watts A (1978) Subsidence of the Atlantic-type continental margin off New York. Earth Planet Sci Lett 41:1-13

Sun Z, Zhong ZH, Zhou D et al (2003) Deformation mechanism of red river fault zone during cenozoic and experimental evidences related to Yinggehai Basin formaiton (in Chinese). J Trop Oceanogr 22(2):1-9

Taylor B (1983) Origin and history of the South China Sea basin. In Hayes DE (ed) The tectonic and geologic evolution of SouthEastern Asia Seas Islands, Part 2, edited by Hayes DE Geophys Monogr, AGU, Washington 27:23-56

Tian S S (2010) Post-rift tectonic subsidence and paleo topography (in Chinese)

Wang GF, Wu CL, Zhou JY et al (1998) Sequence stratigraphic analysis of the tertiary in the Qiongdongnan basin (in Chinese). Exp Petrol Geol 20(2):124-128

Wang ZW, Sun Z, Qiu N et al (2013) The crustal structural of ChangChang sag, deepwater area of Qiongdongnan basin (in Chinese). Mar Geol Front (in press)

Watts AB, Ryan WBF (1976) Flexure of the lithosphere and continental margin basins. Tectonophysics 36:25-44

Westaway R (2002) Geomorphological consenquences of weak lower continental crust, and its significance for studies of uplift, landscape evolution, and the interpretation of river terrace sequences. Netherlands J Geosci 81(3-4):283-303

Wu NY, Zeng WJ, Song HB et al (2003) Tectonic subsidence of the South China Sea (in Chinese). Mar Geol Quat Geol 23(1):55-65

Xiang HF, Han ZJ, Guo SM et al (2004) Processing about quantitative study of large-scale strike-slip movement on red river fault zone (in Chinese). Adv Earth Sci 19:56-59

Xie X, Muller RD, Li S, Gong Z, Sterinberger B (2006) Origin of anomalous subsidence along the Northern South China Sea margin and its relationship to dynamic topography. Mar Petrol Geol 23:745-765
Xie WY, Zhang YW, Sun Z et al (2007) Characteristics and formation mechanism of faults in Qiongdongnan basin (in Chinese). Mar Geol Quat Geol 27(1):71-78

Xie WY, Zhang YW, Sun Z et al (2008) The mechanism research of the formation of the QWiongdongnan basin during the Cenozoic through modeling experiments (in Chinese). Earth Sci Front 15(2):232-241

Yin XY, Ren JY, Pei JX et al (2010) Quantitative calculation on fault activity and fault propagation mechanism in Qiongdongnan basin, South China Sea (in Chinese). Geol J China Uni 16(3):388-396

Yuan YS, Yang SC, Hu SB et al (2008) Tectonic subsidence of Qiongdongnan basin and tis main contrl factors (in Chinese). Chin J Geophys 51(2):376-383

Zhang GC (2010) Tectonic evolution of deepwater area of northern continental margin in South China Sea (in Chinese). Acta Petrolei Sinica 31(4):528-541

Zhang ZJ, Liu YF, Zhang SF et al (2010) The depth-depended of crustal extension beneath Qiongdongnan basin area and its tectonic implications (in Chinese). Chin J Geophys 53(1):57-66

Zhao MW (1989) Discussion on the growth index of fault (in Chinese). Exp Petrol Geol 11(3):250-254

Zhao ZX, Sun Z, Xie H et al (2011) Baiyun deepwater cenozoic subsidence and lithospheric stretching deformation (in Chinese). Chin J Geophys 54(12):3336-3343

Zhong ZH (2000) Reserch on the structral deformation and hydrocarbon of Qiongdongnan basin (in Chinese)

Zhou D, Ru K, Chen H-Z (1995) Kinematics of Cenozoic extension extension on the South China Sea continental margin and its implication for the tectonic evolution of the region. Tectonophysics 251:161-177

Zhu WL, Zhong K, Li YC et al (2012) Characteristics of hydrocarbon accumulation and exploration potential of the northern South China Sea Deep-water Basins (in Chinese). Chin Sci Bull 57(20):1833-1841 